D. Nelipa, Dr. Sc. (Polit.), Assoc. Prof., orcid.org/0000-0002-5363-3990,

S. Rudenko, Dr. Sc. (Philos.), Prof., orcid.org/0000-0001-9069-0989,

V.Teremko, Cand. Sc. (Polit.), Assoc. Prof., orcid.org/0000-0002-1774-0246,

S. Vnuchko, Cand. Sc. (Polit.), Assoc. Prof., orcid.org/0000-0001-9176-1304

\title{
IMPROVING THE QUALITY OF CIVIL SERVICE MANAGEMENT IN UKRAINE
}

Purpose. Improving the quality policy of managing the civil service of Ukraine through the use of foreign experience in implementing the "Lean system".

Methodology. In the study, the authors used general methods of scientific knowledge. In particular:

a) empirical research methods: selection of factual material on reforming the civil service management of the UK and Ukraine, as well as establishing links between the accumulated research results;

b) theoretical research methods: analysis and synthesis, modeling, rising from the abstract to the concrete, and others, which allowed the authors to identify one of the reasons for the ineffective reform of the civil service management of Ukraine.

Findings. The authors briefly examined the history of the formation of the civil service management of Ukraine. It has been noted that the management quality policy in Ukraine was formulated only in the new Law of Ukraine "On Civil Service", which entered into force on May 1, 2016. However, according to results of monitoring of governance reforms conducted by the Agency for Legislative Initiatives in 2017, the quality of public administration remains low. The analysis allowed the authors to establish that one of the reasons for the poor quality of management is non-use of the "Lean system" in the quality management policy. The authors examined the features of lean management, as well as the experience of its implementation in the two largest central governmental departments (UK): the Department for Work and Pensions (DWP) and HM Revenue and Customs (HMRC) (the Department of Revenue and Customs). The results obtained allowed the authors to propose an advanced policy of the quality of civil service management in Ukraine based on the "lean system".

Originality. During the analysis of the process of reforming the management of the civil service of Ukraine, the authors found one of the reasons that reduced the quality of management. The authors proved that this reason is the lack of the principles of "lean management" or "Lean systems" in the quality management policy. To eliminate this cause, the authors proposed taking advantage of the Lean system implementation experience in managing the two largest central government departments in the UK: the Department for Work and Pensions (DWP) and HM Revenue and Customs (HMRC).

Practical value. The results of the study are intended to improve the quality policy of civil service management in Ukraine. The use of the "Lean system", as well as foreign experience in its implementation, will improve the quality of civil service management in Ukraine. The management quality policy based on the "Lean system" will eliminate the deficiencies identified as a result of monitoring public administration reforms and achieve the management quality that is not inferior in effectiveness to civil service management in the European Union.

Keywords: civil service management, UK Civil Service, quality management, lean management, lean system

Introduction. In Ukraine, the Law on Civil Service was adopted in 1993, before the adoption of the Constitution of Ukraine. For comparison, in Great Britain in 1850, Prime Minister W. Gladstone came to the conclusion that it was necessary to create a special class of officials - "civil servants". A distinctive feature of civil servants, according to Gladstone, should be high professionalism aimed at the good of the state, and not favoritism, which brought only harm to the state [1].

During 1993-2011, numerous amendments were made to the Law of Ukraine "On Civil Service". The new Law on Civil Service was adopted on December 17, 2011. However, due to the lack of funds to raise salaries of civil servants, the Law has not come into force yet.

After the Revolution of Dignity, the European Union allocated funds for the creation of a new law "On Civil Service", which had to comply with the European Union Directives. The Law was adopted by the Verkhovna Rada of Ukraine on December 10, 2015. The Law came into force on May 1, 2016, with the simultaneous abandonment of regulations drawn up on the laws of 1993 and 2011.

In the Law of Ukraine "On Civil Service" (2015) for the first time the provisions, which had defined management of civil service, were registered. Some of these provisions are in line with UK laws, on the base of which UK civil service management is organized. However, while these provisions became the Law in Ukraine only in 2015, in the UK they had

(C) Nelipa D., Rudenko S., Teremko V., Vnuchko S., 2020 been adopted by the Parliament in the 1850s. We are talking about the articles of the Law that approve the following rules of civil service management [2]:

1. Withdrawal of political and foster care positions from the civil service.

2. Political impartiality of civil servants.

3. Introduction of the positions of heads of civil service in state bodies, the State Secretary of the Cabinet of Ministers and state secretaries of ministries.

4. Uniform conditions for entering the civil service through an open competition.

5. The system of disciplinary liability of civil servants with an exhaustive list of grounds for penalties.

6. Establishment of an exhaustive list of grounds for the termination of civil service.

It should be noted that only in September 2019, the norm that limited the distribution of labor legislation to civil servants was removed from the Law of Ukraine "On Civil Service" [3]. Until that moment, there was a legal conflict in the legal field of Ukraine, when the labor of citizens of Ukraine was regulated by the law, which had a limited distribution to the work of civil servants.

Thus, over the past few years, under the influence of the European Union, important changes have occurred in the civil service management in Ukraine. These changes were fundamental. They transformed the basis of the civil service management. The laws and regulations governing management policies and public service management have been changed. 
The common practice of the European Union is the constant monitoring of the effectiveness of reforms financed from the budget of the European Union. For this reason in 2017, the Agency for Legislative Initiatives monitored the process of reforming of the civil service management of Ukraine for the money of the European Union and according to its methodology. Along with the positive changes and attained results, monitoring educed the substantial shortcomings in reformation of policy of administration and the civil service management [4].

In the proposed article, the authors will consider the shortcomings in the policy of administration and the civil service management of Ukraine that were identified as a result of monitoring in 2017. The reasons for these shortcomings will be revealed as well. The authors will pay special attention to "lean management", which is actively being introduced into the civil service management and is considered as a synonym for the quality of management in highly developed states. The authors will review the experience of implementing "lean management" in the British civil service. As for the authors, just the lack of principles of lean management in the reforming policy of the civil service management of Ukraine is one of the reasons for the non-compliance of the quality of management with the European Union standards.

Results. The civil service management in any state is guided by certain standards. These standards ensure the quality of the civil service management.

In a general sense, the quality of management is considered as an act of oversight of all actions and tasks necessary to maintain the desired level of excellence. Quality of management includes the determination of a policy of quality, creation and implementation of planning and quality assurance, as well as the quality control and quality improvement. High quality management standards are denoted by the term "total quality management" (TQM). These standards are based on the results of statistics and statistical theories.

When we talk about the quality of civil service management, we mean the specific schemes and methods for managing civil servants that provide higher productivity, a high level of satisfaction, a greater commitment to civil service, as well as more ethical views and behavior at civil service.

The policies, techniques, and methods for managing civil servants, which determine the quality of management, have proven their effectiveness in the history of states with different cultures. In a way, it is the civil servant's culture and the civil service management culture formed in the world history.

The features of the formation of a civil service management culture in various states were investigated by P. Diamond [1], R. Naumenko [5], S. Rudenko [6], J. Meyer-Sahling [7], V. Yakushik [8], et al.

In general, the quality of civil service management is determined by the following key characteristics:

a) a civil servant's satisfaction by his job;

b) self-assessment of productivity in the position held;

c) motivation of work;

d) focus on the civil service;

e) the level of trust within the established organization;

f) willingness to abide formal rules;

g) willingness to report on unethical behavior of colleagues;

h) aversion and the desire to combat such ethical violations as the use of official resources for personal purposes, nepotism, personal and political corruption, etc.

The quality of civil service management primarily depends on the definition of a quality policy. Monitoring of the quality of civil service management in Ukraine, which was carried out by the Agency for Legislative Initiatives in 2017 according to the methodology and at the expense of the European Union, revealed a number of shortcomings. They are set out in the shadow report "Civil Service and Public Administration Reform in Ukraine in 2017" [4]. Analysis of the identified defi- ciencies leads us to the following conclusion. The main part of the shortcomings in the management and reforming of the civil service management of Ukraine is the result of a dual policy of quality management in Ukraine. The duality of the quality management policy is manifested, first of all [4]:

1. In weak and biased management, in the base of which favoritism and party affiliation, rather than professional qualities and work experience, still play an important role.

2 . In the uncertainty of resource provision and sustainable financing of public administration reform.

3. Inadequate and inconsistent communication of public administration reform.

4. The low level of implementation of modern information and communication technologies in civil service management.

From our point of view, the dual policy of the quality of civil service management in Ukraine is explained by uncertainty in the basic ideas, ideals and values that consolidate the Ukrainian nation. Namely:

1. The lack of clear approaches and methods of self-determination of the Ukrainian nation [9].

2 . The lack of a national idea that not only consolidates the nation, but also determines the ideal image of the Ukrainian politician and state manager [10].

3. Duality in the choice of strategy for the development of Ukrainian politics between East and West [11].

4. The absence of clearly defined and controlled principles of public administration, which determine the personnel policy of the civil service of Ukraine [12].

Uncertainty of the quality management policy of the civil service of Ukraine leads to inefficient management of civil servants. In the management of the civil service of Ukraine is still missing [4]:

a) special programs for the development and support of the civil service management function;

b) indicators of the effectiveness, efficiency and quality of work of personnel management services and civil service managers in governmental bodies;

c) the unified electronic information and analytical system of personnel management in the civil service.

The lack of a clear quality policy of civil service management makes it difficult to link the system of evaluating the results of work of civil servants with financial motivation, or bonuses. As a result, the focus on civil service and professional growth of civil servants is declining. In a chain reaction, this leads to a greater decrease in the quality of management and the effectiveness of state institutions.

In highly developed countries, the policy of reforming the management of civil service is guided by the principles of the so-called "lean management". The term "lean management" has come to be regarded as a synonym for the term "quality management".

If to consider the "lean management" as a whole, it is based on the management concept, which was developed in the Japanese manufacturing industry to minimize waste within the production system without compromising productivity. Lean Management is associated with a management philosophy based on the Toyota Production System (TPS). In the 1990s, this management philosophy was called "lean" or lean system. I. Kolos revealing the meaning of "economical management" writes about the system of economical production or the Toyota Production System [13].

The philosophy of lean management is relevant not only in the economy, but also in other areas of activity. It is considered as the basis of the manager's worldview, which determines the sequence and motivation of his actions [14]. In essence, it becomes the ontology of a successful manager. The formation of this philosophy is carried out by state and public organizations. Let us single out the most famous organizations:

1. "Lean Enterprise Academy", which associates itself with the slogan "The UK Source for Lean Thinking \& Practice" (British source of thinking and practice) [15]. 
2. "Lean Advancement Initiative", which was created at the Massachusetts Institute of Technology. The organization offers an extensive corporate knowledge base and lean management experience covering several areas, including industry, military and healthcare [16].

A comparison of studies of the lean management of Ukrainian scientists with British scientists makes us pay attention to several features:

1. In the studies of Ukrainian scientists, the lean manufacturing system that underlies lean management is not considered as the basis of the civil service management quality policy.

2 . In the lean production system, the main place is given to the workforce, which has a significant part of the responsibility for performing production tasks as a means of increasing the financial value of the production process of the company. Increasing of labor productivity is achieved precisely through the use of knowledge and skills of employees. However, research by Ukrainian scientists focuses on the use of lean manufacturing and lean management in enterprises. Improving the quality of management and professional skills of enterprise employees by Ukrainian scientists is not disputed; however, it is not considered as the central event of lean manufacturing.

3. In the UK since 1979, after the election of the Thatcher government, the civil service began to be reformed on the basis of business models used in the private sector of the economy. Restructuring was based on a market-based approach to the provision of civil services. This allowed reducing the number of personnel in the public service from 554,000 to 440,000 , i.e. approximately $20 \%$ for the period 2006-2014 [17]. For comparison, in Ukraine, after the adoption of amendments to the Law on Civil Service in 2019, it is planned to reduce or transfer to a contract form 14,000 employees out of 240000 civil servants, or $7 \%$, by the end of 2020 [18].

4. The lean manufacturing system is aimed at the continuous perfection of personnel operations by involving the latest information and communication technologies. The effectiveness of staff is achieved by combining the knowledge and experience of staff with the introduction of new technologies. In the studies by Ukrainian scientists, the technical and technological excellence of the "workplace", as well as the integration of intellectual potential with digital technologies lack adequate attention.

The lean production system and lean management are considered by Ukrainian scientists exclusively as a tool to increase the efficiency of the national economy [13]. In fact, this approach narrows the perception of lean management principles. In the article "Lean' in the UK Civil Service: from the theory of improvement to the varied realities of costs cutting ", D. Martin examined the ways in which the UK civil service would use a work restructuring approach that has historically been associated with manufacturing [17]. Martin reviewed the implementation features of the lean manufacturing system (Martin calls it the Lean system) in the UK's two largest central government departments: the Department for Work and Pensions (DWP) and HM Revenue and Customs (HMRC) (Department of Revenue and Customs). In 2016, $40 \%$ of all civil servants in the UK were employed in these two departments.

From Martin's research mainly the experience that will improve the quality policy of civil service management in Ukraine is singled out by us.

First, the Lean System is focused on the continuous professional growth of civil service employees. The basis of the quality policy of civil service management should be financial motivation (bonuses and social benefits), which in a market economy increases competition when entering the civil service and during the performance of duties in the civil service. Lean systems are based on a high level of standardization, but the high professional qualities of employees allow continuous improvement of current operating procedures.

Second, the implementation of the Lean system is not aimed at reducing staff. For example, in the UK over 8 years (from 2006-2014), the staff decreased by $20 \%$ [17]. In Ukraine, over the last year alone, it was planned to reduce up to $7 \%$ of civil servants [18]. The implementation of the Lean system is aimed at improving the quality of management and the effectiveness of the provision of civil services. For example, in the UK, the implementation of the Lean System is expected to increase public service productivity by $15 \%$ in the first year, and by $5 \%$ in each subsequent year [17]. Staff reduction is a side effect of the implementation of the Lean system, and not its main goal.

Third, the implementation of the Lean system leads to the creation of a new "infrastructure" of civil service, in which the latest information and communication technologies occupy the main place. Adherence to bureaucracy and traditions are the main reasons for the inefficiency of civil service. Therefore, the continuous improvement of the "infrastructure" of civil service is a kind of "antidote" prone to conservative management policies.

Fourth, as Martin notes, the main feature of the implementation of the "Lean system" in the workplace is a certain standardization of the employee's operational actions [17]. On the one hand, this limits the initiative of the staff, but on the other hand, it makes the work of the staff more predictable. The standardization of operational activities facilitates the personnel management. An employee cannot do less than what is required by instructions, which allows him/her to determine the quality of his work.

Fifth, the Lean System aims to stimulate the work of civil servants. Ultimately, it leads to the fact that employees have to increase the pace of work in order to compensate for the reduction in the number of staff and the political and economic program to reduce government spending. The standardization of operational actions does not allow the employee to work more slowly than prescribed in the instructions. At the same time, each new instruction provides for higher employee productivity than the previous instruction determined.

Conclusions. Summing up the results of our study, we can conclude the following. Against the background of the tendency to reduce the financing of civil service, which is observed not only in Ukraine, but also in the world practice, the introduction of Lean systems in the quality policy of civil service management is the obvious and only possible way to improve the quality of civil services. The lean approach is based on a number of universal principles that allow us to improve the quality of civil service management and the level of service provision by civil services using the professional qualities of employees, the ability to standardize their actions, and also increase the efficiency of intellectual work by introducing new digital technologies.

\section{References.}

1. Diamond, P. (2013). Governing Britain: Power, Politics and the Prime Minister. I. B. Tauris.

2. Law of Ukraine 'On Civil Service' (2019). Revision on October 18, 2019. Retrieved from https://zakon.rada.gov.ua/laws/ show $/ 889-19$ ?lang $=$ uk.

3. On amendments to some laws of Ukraine on rebooting power (2019). Adoption on September 19, 2019. Retrieved from https://zakon.rada.gov.ua/laws/show/117-20?lang=en.

4. Civil Service and Public Administration Reform in Ukraine in 2017 (Shadow Report) (2018). Agency for Legislative Initiatives. Retrieved from https://parlament.org.ua/wp-content/ uploads/2018/05/Shadow Report PAR 2017.pdf.

5. Naumenko, R. (2017). Management for the Society of the Future: New Trends in the Training for Civil Servants in Ukraine. Philosophy and Cosmology, 19, 117-125.

6. Rudenko, S., Bazaluk, O., Tsvykh, V., \& Kalmuk, I. (2019). The Role of Philosophical Disciplines in Educational Strategies for Specialist Training in the Field of Public Administration. Naukovyi Visnyk Natsionalnoho Hirnychoho Universytetu, (3), 158-163. https://doi.org/10.29202/nvngu/2019-3/22. 
7. Meyer-Sahling, J., Schuster, C., Sass Mikkelsen, K., \& Shundi, A. (2018). The quality of civil service management in Albania: evidence from a survey of central government civil servants and public employees. Retrieved from https://nottingham-repository.worktribe.com/output/1648865/the-qualityof-civil-service-management-in-albania-evidence-from-asurvey-of-central-government-civil-servants-and-public-employees.

8. Yakushik, V. (2019). Importance of Inter-Civilizational and Intra-Civilizational Dialogue in National State Consolidation and Development. Ukrainian Policymaker, 4, 85-90. https:// doi.org/10.29202/up/4/11.

9. Pohribna, D., \& Tytarenko, V. (2019). The Ways and Means of the Ukrainian Nation's Self-Determination: a Philosophical Look into the Future by Julian Vassyian. Future Human Image, 11, 72-82. https://doi.org/10.29202/fhi/11/8.

10. Bazaluk, O., \& Blazhevych, T. (2016). The Image of an Ideal Ukrainian Politician. Ukrainian National Idea. Future Human Image, 6, 24-30.

11. Sodomora, P. (2018). Ukrainian Philosophical Thought at the Brink between East and West. Ukrainian Policymaker, 3, 65-71. https://doi.org/10.29202/up/3/9.

12. Naumenko, R. (2018). Philosophy of Public Governance: Manpower Policy of Modern Ukraine in the Context of Globalization. Philosophy and Cosmology, 20, 106-112. https:// doi.org/10.29202/phil-cosm/20/9.

13. Kolos, I. (2016). Lean management: foreign and domestic experience. Retrieved from http://dspace.nuft.edu.ua/jspui/ bitstream/123456789/25917/1/Kolos-2016-2.pdf.

14. Bazaluk, O. (2019). The Revival of the Notion of Arete in Contemporary Philosophy. Schole, 13.1, 198-207. https://doi. org/10.25205/1995-4328-2019-13-1-198-207.

15. Lean Enterprise Academy (2019). Retrieved from http:// www.leanuk.org/.

16. Lean Advancement Initiative (2019). Massachusetts Institute of Technology. Retrieved from https://dspace.mit.edu/ handle/1721.1/1785.

17. Martin, D. (2017). 'Lean' in the UK Civil Service: from the theory of improvement to the varied realities of costs cutting. La Nouvelle Revue du Travail, 10, 2017. https://doi. org/10.4000/nrt.3117.

18. New in legislation: The government not only allowed officials to be quickly dismissed, but also deprived them of additional payments. kadrovik.ua, 09/20/2019. Retrieved from https://www. kadrovik.ua/novyny/nove-v-zakonodavstvi-uryad-ne-tilkydozvolyv-shvydko-zvilnyaty-chynovnykiv-shche-y-pozbavyv.

\section{Підвищення якості управління державною службою України}

\section{Д. В. Неліпа, С. В. Руденко, В.В.Теремко, С. М. Внучко}

Київський національний університет імені Тараса Шевченка, м. Київ, Україна, е-mail: rudenkosrg@gmail.com

Мета. Удосконалення політики якості управління державний службою України за рахунок використання закордонного досвіду впровадження «Lean системи».

Методика. У дослідженні автори використовували загальні методи наукового пізнання. Зокрема:

а) емпіричні методи дослідження: відбір фактичного матеріалу із реформування управління державної служби Великої Британії та України, а також встановлення зв'язків між накопиченими результатами досліджень;

б) теоретичні методи дослідження: аналіз і синтез, моделювання, сходження від абстрактного до конкретного та інші, шо дозволили авторам виявити одну з причин неефективного реформування управління державною службою України.
Результати. Автори коротко розглянули історію формування управління державною службою України. Відзначено, що політика якості управління в Україні була сформульована тільки в новому Законі України «Про державну службу», який набув чинності 1 травня 2016 року. Однак, як засвідчив моніторинг реформування управління, проведений Agency for Legislative Initiatives у 2017 році, якість державного управління як і раніше залишається низькою. Проведений аналіз дозволив авторам встановити, що однією 3 причин низької якості управління є невикористання в політиці якості управління «Lean системи». Автори розглянули особливості бережливого управління, а також досвід його впровадження у двох найбільших центральних урядових департаментах Великобританії: the Department for Work and Pensions (DWP) (Департамент праці та пенсій) і HM Revenue and Customs (HMRC) (Департамент доходів і митниці). Отримані результати дозволили авторам запропонувати удосконалену політику якості управління державною службою України на засадах «lean системи».

Наукова новизна. У ході аналізу процесу реформування управління державною службою України автори виявили одну з причин, що знижує якість управління. Автори довели, що такою причиною є відсутність у політиці якості управління принципів «бережливого управління» або «Lean системи». Для усунення цієї причини автори запропонували скористатися досвідом упровадження «Lean системи» в управління двох найбільших центральних урядових департаментів Великобританії: the Department for Work and Pensions (DWP) (Департамент праці та пенсій) і HM Revenue and Customs (HMRC) (Департамент доходів і митниці).

Практична значимість. Отримані результати дослідження призначені для вдосконалення політики якості управління державною службою України. Використання «Lean системи», а також закордонного досвіду іiї впровадження, підвищить якість управління державною службою України. Політика якості управління, що заснована на «Lean системі», дозволить усунути недоліки, виявлені за результатами моніторингу реформ державного управління й досягти якості управління, що за ефективністю не поступається управлінню державною службою в державах Європейського Союзу.

Ключові слова: управління держсавною службою, Державна служба Великобританії, якість управління, ощадливе управління, «еап система»

\section{Повышение качества управления государственной службой Украины}

$$
\begin{gathered}
\text { Д. В. Нелипа, С. В. Руденко, В.В. Теремко, } \\
\text { С. Н. Внучко }
\end{gathered}
$$

Киевский национальный университет имени Тараса Шевченко, г. Киев, Украина, e-mail: rudenkosrg@gmail.com

Цель. Усовершенствование политики качества управления государственной службой Украины за счет использования зарубежного опыта внедрения «Lean системы».

Методика. В исследовании авторы использовали общие методы научного познания. В частности:

а) эмпирические методы исследования: отбор фактического материала по реформированию управления государственной службой Великобритании и Украины, а также установление связей между накопленными результатами исследований;

б) теоретические методы исследования: анализ и синтез, моделирование, восхождение от абстрактного к конкретному и другие, которые позволили авторам выявить 
одну из причин неэффективного реформирования управления государственной службой Украины.

Результаты. Авторы кратко рассмотрели историю формирования управления государственной службой Украины. Отмечено, что политика качества управления в Украине была сформулирована только в новом Законе Украины «Про державну службу», который вступил в силу 1 мая 2016 года. Однако, как показал мониторинг реформирования управления, проведенный Agency for Legislative Initiatives в 2017 году, качество государственного управления по-прежнему остается низким. Проведенный анализ позволил авторам установить, что одной из причин низкого качества управления является неиспользование в политике качества управления «Lean системы». Авторы рассмотрели особенности бережливого управления, а также опыт его внедрения в двух крупнейших центральных правительственных департаментах (the largest central government departments) Великобритании: the Department for Work and Pensions (DWP) (Департаменте труда и пенсий) и HM Revenue and Customs (HMRC) (Департаменте доходов и таможни). Полученные результаты позволили авторам предложить усовершенствованную политику качества управления государственной службой Украины на основе «lean системы».

Научная новизна. В ходе анализа процесса реформирования управления государственной службой Украины авторы обнаружили одну из причин, снижающих качество управления. Авторы доказали, что такой причиной является отсутствие в политике качества управления принципов «бережливого управления» или «Lean системы». Для устранения этой причины авторы предложили воспользоваться опытом внедрения «Lean системы» в управление двух крупнейших центральных правительственных департаментов (the largest central government departments) Великобритании: the Department for Work and Pensions (DWP) (Департамент труда и пенсий) и НM Revenue and Customs (HMRC) (Департамент доходов и таможни).

Практическая значимость. Полученные результаты исследования предназначены для совершенствования политики качества управления государственной службой Украины. Использование «Lean системы», а также зарубежного опыта ее внедрения, повысит качество управления государственной службой Украины. Политика качества управления, основанная на «Lean системе», позволит устранить недостатки, выявленные в результате мониторинга реформ государственного управления и достичь качества управления, которое по эффективности не уступает управлению государственной службой в государствах Европейского Союза.

Ключевые слова: управление государственной службой, Государственная служба Великобритании, качество управления, бережливое управление, «lеап система»

Recommended for publication by A. P. Savkov, Doctor of Sciences in Public Administration. The manuscript was submitted 11.04.19. 